\title{
RECENZIÓ BARBARA COLOROSO (2014) ZAKLATÓK, ÁLDOZATOK, SZEMLÉLŐK: AZ ISKOLAI ERŐSZAK CÍMÜ MỨVÉRŐL
}

\author{
A recenzió szerzője: \\ Ladányi Lili \\ Eszterházy Károly Egyetem (Magyarország)
}

Első szerző e-mail címe:

ladanyi.lili@jgypk.szte.hu

\author{
Lektor: \\ Mező Ferenc (Ph.D) \\ Eszterházy Károly Egyetem (Magyarország) \\ Dr. Mező Katalin (Ph.D) \\ Debrecemi Egyetem (Magyarország)
}

Ladányi Lili (2020): Recenzió Barbara Coloroso (2014) Zaklatók, áldozatok, szemlélők: az iskolai erôszak címú művéről. Különleges Bánásmód, 6. (4). 103-105. DOI 10.18458/KB.2020.4.103
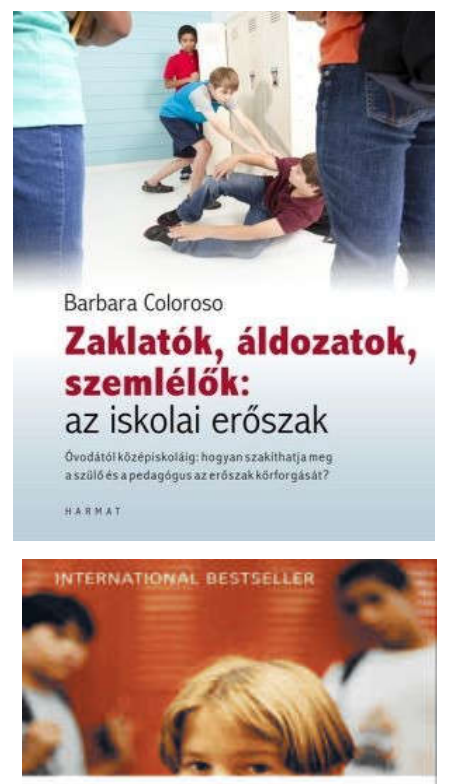

The Bully, the Bullied, and the Bystander

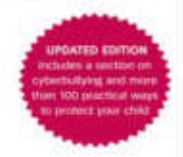

From preschoof to Hight schoot- How Parents and BARBARA COLOROSO
A recenzió alapjául szolgáló mű bibliográfiája:

Barbara Coloroso (2014). Zaklatók, áldozatok, szemlélők: az iskolai erőszak - Óvodától középiskoláig: hogyan szakíthatja meg a szülő és a pedagógus az erôszak körforgását? Hartman Kiadó, Budapest. ISBN:9789632881966

Kulcsszavak: iskolai erőszak, zaklatás

Diszciplinák: pedagógia, szociológia

Bibliography of the subject of this recension:

Barbara Coloroso (2010). The Bully, the Bullied, and the Bystander: From Preschool to High School--How Parents and Teachers Can Help Break the Cycle. HarperCollins. New York.

Keywords: school violence, bullying

Discipline: pedagogy, sociology 
Manapság egyre nagyobb érdeklődés mutatkozik az iskolai zaklatás témája iránt, a szülők és az iskolák is keresik a leghatékonyabb módszereket, hogy visszaszorítsák a bántalmazások előfordulását. Alapvetően két nézet uralkodik az iskolai zaklatások kapcsán. Az egyik szerint ez egy teljesen normális jelenség, mindig is létezett, de az utóbbi időben túlzottan fókuszba került, és a környezet közbeavatkozása az, ami súlyosbítja a helyzetet. A másik szerint az utóbbi időben túlzott mértéket öltött bántalmazást a lehetô legtöbb erőforrást mozgósítva kell megállítani, mielőtt még túl késő lenne. Barbara Coloroso könyve határozottan az utóbbi véleményt osztja: A szerző saját bevallása szerint egy, a lakóhelyén történt iskolai lövöldözés ihlette, amelyről később kiderült, hogy hátterében iskolai zaklatás állt.

Könnyen olvasható, hétköznapi nyelven, mégis tudományosan alátámasztott módon szólítja meg az olvasót. A könyv alcíme („Óvodától középiskoláig: hogyan szakíthatja meg a szülő és a pedagógus az erôszak körforgását?”) kissé félrevezető lehet, mert ugyan rengeteg pedagógusok számára is használható tippet tartalmaz a bántalmazás visszaszorításához, intézményi szinten kevés segítséget nyújt egy zaklatás elleni komplex program kidolgozásához. Viszont például áboroztatók számára, akik pár napig egyszerre töltenek be szülői és pedagógusi feladatokat is, nagyon jól használható könyv.

A könyv tartalmilag két részre oszlik. Az első részben („A zaklató, a szemlélő és az áldozat”) a bántalmazásban részt vevő személyek egy hat felvonásos tragikus színjáték szereplőiként jelennek meg, csak sajnos ez a színdarab és a szereplők is valóságosak. Érzékletes példákon keresztül mutatja be az áldozatok és a bántalmazók lelki állapotát, szívbe markoló olvasni a többnyire tragédiával végződő eseteket, amelyekből már rögtön az előszóban is elénk tár jópárat, ezzel is igazolván a könyv létrejöttét. Ugyanakkor azt leírja, hogy a forgatókönyvek, amelyek ezekhez a színdarabokhoz és szerepekhez készültek, átírhatóak, van kiút az erôszakból. Beletekinthetünk a bántalmazó, az áldozat és a szemlélődők lelki világába és gondolataiba. Elmagyarázza a zaklatás négy ismertetőjelét, hogy az mindenki számára világosan elkülönüljön a hétköznapi konfliktusoktól: egyenlőtlen erôviszonyok, a fájdalomokozás szándéka, fenyegetettség, terror. Tárgyilagos leírást kapunk a zaklatás különböző módszereiről és eszközeiről, valamint elénk tárja a zaklató jellemrajzát is. Elmagyarázza, hogy senki sem születik zaklatónak, a zaklatás tanult viselkedésforma, és ebben kiemelkedő a közvetlen környezet szerepe. Bár a zaklatók eltérnek egymástól kinézetükben, módszereikben és eszközeikben, egy kulcsfontosságú tulajdonságban megegyeznek, ez pedig a megvetés: a másik személy alacsonyabb rendűnek, értéktelennek tekintése. Ez teszi lehetôvé számukra, hogy bűntudat, szégyenérzet és megbánás nélkül bántalmazzák embertársukat.

Az áldozatok ezzel szemben általában bizonytalanok és félnek önállóan fellépni a bántalmazás ellen vagy beszélni róla. Húsz különböző ürügyet sorol fel, ami miatt valaki könnyedén válhat a bántalmazók célpontjává, és ami miatt az áldozatok gyakran úgy érzik, hogy megérdemlik a bántalmazást. Ez is közrejátszik abban, hogy környezetük számára 
gyakran csak egy tragédia bekövetkezte után derül ki a bántalmazás megléte. A szerző a szülők és pedagógusok számára a korai felismeréshez nyújt segítséget az úgynevezett „vészjelek” felsorolásával.

A szemlélődők csoportját statisztákhoz hasonlítja, akik aktív vagy épp passzív részvételükkel közvetve járulnak hozzá a zaklató támogatásához, legtöbbször a tömegbe olvadva fel sem ismerve egyéni tettük súlyát. Ők maguk az áldozathoz hasonlóan szintén gyakran bizonytalanok, és nincs bátorságuk a beavatkozáshoz, vagy saját biztonságukat féltik, azért nem lépnek semmit. A szerző kihangsúlyozza, hogy nincs ártatlan szemlélődő, elsődlegesen az ő kezükben van a bántalmazás megállításának lehetősége.

A második részben (Az erôszak körforgásának megszakítása - a törődés körforgásának megteremtésével) a megelőzés fontosságára helyezi a hangsúlyt, elsősorban a szülők számára kínál ötleteket az egészséges, gondoskodó családi légkör kialakításához, amelyek csökkenthetik a gyermekek zaklatásának valószínűségét. Bemutat három családmodellt, és azt, hogy melyik családszerkezet miként járulhat hozzá a bántalmazó, az áldozat vagy a bántalmazáshoz asszisztáló szemlélő típusú gyermek fejlődéséhez. Coloroso stratégiákat kínál a zaklató magatartásának orvoslására, a zaklatás áldozatainak támogatására és a szemlélődők beavatkozásra ösztönzésére.
Azt tanácsolja a szülőknek és a pedagógusoknak, hogy kezeljék a bántalmazást a bizalomteljes légkör megteremtése mellett határozott korlátok felállításával, amelyek megszegése esetén a büntetés helyett a fegyelmezés eszközét válasszák szankcióként. Teremtsenek lehetőséget a gyermekeknek, hogy megmutathassák a bennük rejlő kedvességet és jóakaratot társaik irányába, pozitív párbeszédek révén segítsék a szociális készségek fejlődését, és az empátia kialakulását.

A zaklatás nem szűnik meg magától, foglalkozni kell vele. A családoknak és az iskoláknak karöltve kell programokat kidolgozniuk annak biztosítása érdekében, hogy minden gyermek biztonságos, kedves és gondoskodó környezetben nevelkedhessen otthon és az iskolában is. A Zaklatók, áldozatok, szemlélôk: az iskolai erôszak címû könyv ebben a folyamatban lehet segítségünkre.

\section{Irodalom}

Coloroso, B. (2014). Zaklatók, áldozatok, szemlélôk: az iskolai erôszak - Óvodától középiskoláig: hogyan szakíthatja meg a szülő és a pedagógus az erőszak körforgását? Harmat Kiadó, Budapest. 